\title{
PENERAPAN METODE DISKUSI DAN PRESENTASI UNTUK MENINGKATKAN MINAT DAN HASIL BELAJAR SISWA DI KELAS XI IPS-1 SMA NEGERI 1 BAGAN SINEMBAH
}

\author{
Dortiana Marpaung \\ Surel: dmarpaung68@gmail.com
}

\begin{abstract}
The purpose of this study are: 1) To increase learning interest and completeness of learning outcomes by applying the method of discussion and presentation in class XI IPS-1 Bagan Sinembah 1 High School. This research was carried out in the classroom including classroom action activities (PTK) in the form of initial reflection activities and conducting observations to identify problems that occur in the classroom, planning learning, implementing actions, observation and reflection. The PTK research findings are: 1) Student learning outcomes in cycle I of 40 students there were 26 students who completed or around (65\%) and 14 students who did not complete or around (35\%), with an average of 73.8; 2) Student learning outcomes in cycle II of 40 students there were 36 students who completed or around (90\%) and 4 students who did not complete or around (10\%), with an average of 79.87. It can be concluded that the application of discussion and presentation learning methods can increase student interest and learning outcomes in Class XI IPS-1 Bagan Sinembah 1 High School District. Rokan Hilir.
\end{abstract}

Keywords: Learning Method, Discussion and Presentoation, Learning Outcomes

\begin{abstract}
ABSTRAK
Tujuan penelitian ini adalah: 1) Untuk meningkatkan minat belajar dan ketuntasan hasil belajar dengan penerapan metode diskusi dan presentasi di kelas XI IPS-1 SMA Negeri 1 Bagan Sinembah. Penelitian ini dilaksanakan dalam kelas meliputi kegiatan pelaksanaan tindakan kelas (PTK) berupa kegiatan refleksi awal dan melakukan observasi untuk mengidentifikasi permasalahan yang terjadi di kelas, perencanaan pembelajaran, pelaksanaan tindakan, observasi dan refleksi. Adapun temuan penelitian PTK ini adalah: 1) Hasil belajar siswa pada siklus I dari 40 orang siswa terdapat 26 siswa yang tuntas atau sekitar $(65 \%)$ dan 14 orang siswa yang tidak tuntas atau sekitar $(35 \%)$, dengan rerata 73,$8 ; 2)$ Hasil belajar siswa pada siklus II dari 40 orang siswa terdapat 36 siswa yang tuntas atau sekitar (90\%) dan 4 orang siswa yang tidak tuntas atau sekitar (10\%), dengan rerata 79,87. Dapat ditarik kesimpulan bahwa penerapan metode pembelajaran diskusi dan presentasi dapat meningkatkan minat dan hasil belajar siswa di Kelas XI IPS-1 SMA Negeri 1 Bagan Sinembah Kab. Rokan Hilir.
\end{abstract}

Kata Kunci: Metode Pembelajaran, Diskusi dan Presentoasi, Hasil Belajar 

PENDAHULUAN

Bahasa tidak dapat dipisahkan dari kehidupan manusia. Bahasa digunakan oleh manusia untuk berkomunikasi dengan manusia lain. Bahasa mempunyai fungsi intelektual, sosial, dan emosional.

Dalam hal ini, setiap pengajaran bahasa pada dasarnya bertujuan agar para pembelajar atau para siswa mempunyai keterampilan berbahasa. Terampil berbahasa berarti terampil menyimak, terampil berbicara, terampil membaca, dan terampil menulis. Keempat keterampilan tersebut merupakan satu kesatuan yang tidak dapat dipisahkan karena keterampilan yang satu akan memengaruhi keterampilan yang lain. Dilihat dari sifatnya, keempat keterampilan tersebut dapat dikelompokkan menjadi dua, yaitu keterampilan berbahasa yang bersifat reseptif (menyimak dan membaca) dan keterampilan berbahasa yang bersifat produktif (menulis dan berbicara)

Dalam standar kompetensi mata pelajaran Bahasa Indonesia dijelaskan bahwa belajar bahasa adalah belajar berkomunikasi dan belajar sastra adalah belajar menghargai manusia dan nilai-nilai kemanusiaan, oleh karena itu pembelajaran Bahasa Indonesia diarahkan untuk meningkatkan kemampuan siswa untuk berkomunikasi dalam Bahasa Indonesia, baik secara lisan maupun tertulis serta menghargai karya cipta bangsa Indonesia.
Dalam kurikulum Tingkat Satuan Pendidikan (KTSP 2006) disebutkan bahwa pembelajaran bahasa Indonesia diarahkan untuk meningkatkan kemampuan peserta didik dalam berkomunikasi dengan menggunakan bahasa Indonesia yang baik dan benar, baik secara lisan maupun tulis, serta menumbuhkan apresiasi terhadap karya sastra. Pengenalan budi pekerti yang baik, pengasahan kepekaan rasa kemanusiaan dan kepedulian sosial, penumbuhan apresiasi budaya dan penyaluran gagasan, imajinasi dan ekspresi secara kreatif dan konstruktif dapat dilakukan melalui berbagai jenis karya sastra.

Sastra yang merupakan bagian dari mata pelajaran Bahasa Indonesia memiliki fungsi utama sebagai penghalus budi, peningkat kepekaan rasa kemanusiaan, dan kepedulian sosial, menumbuhkan apresiasi budaya dan penyalur gagasan, imajinasi dan ekspresi secara kreatif dan konstruktif, baik secara lisan maupun tertulis. Melalui sastra siswa diajak untuk memahami, menikmati, dan menghayati karya sastra. Pengetahuan tentang sastra hanyalah sebagai penunjang dalam mengapresiasi karya sastra, (Depdiknas, 2002).

Pembelajaran sastra di sekolah dimaksudkan untuk meningkatkan kemampuan pembelajar dalam mengapresiasikan suatu karya sastra. Dari proses apresiasi ini, diharapkan muncul daya nalar, daya kritis, dan daya khayal dari diri pembelajar. 
Penalaran yang runtut dan didukung oleh ketajaman analisis akan membantu pembelajar untuk mempunyai kepekaan terhadap gejala atau fenomena sosial yang terjadi dalam masyarakat.

\section{Rahmanto}

menyatakan bahwa pembelajaran sastra dapat membangun dan membantu pendidikan secara utuh bila pembelajaran itu selain dapat meningkatkan keterampilan berbahasa juga dapat mengembangkan cipta rasa, menunjang pembentukan watak pembelajar, dan meningkatkan pengetahuan dan pemahaman budaya. Tujuan-tujuan itu dapat dicapai setelah pembelajar menjalani proses apresiasi terhadap karya-karya sastra.

Selanjutnya di dalam KTSP telah diketengahkan beberapa butir pembelajaran sastra yang bertujuan agar pembelajar (1) mampu memahami dan menghayati karya sastra, (2) mampu menulis prosa, puisi, dan drama, (3) mampu menggali nilai-nilai moral, sosial dan budaya dalam karya sastra Indonesia dan karya sastra terjemahan, (4) mampu menulis krestif, (5) mampu membuat tanggapan terhadap tulisan kreatif, dan mampu membuat kritik dan esai sastra.

Menulis naskah drama sebagai salah satu bagian dari menulis sastra yang dapat dimanfaatkan untuk meningkatkan keterampilan menulis siswa. Bukan hanya menulis rapi, melainkan penulisannya juga harus sesuai dengan kaidah penulisan naskah drama. Menulis naskah drama yang sesuai dengan kaidah penulisan naskah drama dapat dijadikan sebagai bentuk penyesuaian awal agar mereka dapat menulis naskah drama dengan baik. Oleh karena itu, menulis naskah drama sebagai salah satu keterampilan bersastra perlu mendapat perhatian yang serius dalam pengajaran bahasa dan sastra Indonesia di sekolah. Sehubungan dengan hal tersebut, maka pengajaran menulis naskah drama harus ditingkatkan.

Melihat pentingnya pengajaran keterampilan menulis naskah drama, sebagai motivator dan fasilitator, guru harus berusaha untuk menarik minat siswa agar lebih tertarik dan bersemangat dalam pembelajaran tidak monoton dan menjenuhkan yang masih menggunakan metode konvesional yaitu sepenuhnya menggunakan metode ceramah. Seperti yang diungkapkan Mursini (2012) bahwa dalam proses belajar mengajar guru berperan sebagai fasilitator yang membantu anak didik mengembangkan keterampilan berbahasanya.

Anak didik merupakan subjek utama, tidak hanya sebagai objek belaka. Karena itu, ciri-ciri dan kebutuhan anak didik harus dipertimbangkan dalam segala keputusan yang terkait dengan pengajaran. Bahan pelajaran dan kegiatan pembelajaran dapat menjadi lebih bermakna bagi anak didik jika berhubungan dengan kebutuhan anak 
didik yang berkaitan dengan pengalaman dan minat anak didik. Karena pengalaman dan minat anak didik dalam lingkungan harus dijadikan pertimbangan dalam pengambilan keputusan pengajaran dan pembelajaran untuk membuat pelajaran lebih bermakna bagi anak didik. Kurang pemahaman dalam menulis naskah drama merupakan pertanda yang kurang baik dalam pembelajaran. Terlebih dalam proses belajar bahasa dan sastra dalam meningkatkan perkembangan intelektual siswa. Akibatnya mereka malas belajar dan berpikir. Hal itu akan berdampak dalam perkembangan kognitif, afektif dan psiomotorik. Selain itu, tidak tertutup kemungkinan siswa akan merasa bahwa belajar bahasa dan sastra, khususnya menulis sama sekali tidak penting, hal ini disebabkan oleh kesulitan siswa menentukan unsur instrinsik drama.

Dari hasil observasi teman sejawat dan refleksi diri guru dalam mengajar di SMA Negeri 1 bagan Sinembah, Kab. Rokan Hilir, Provinsi Riau. Pada mata pelajaran Bahasa Indonesia masih ada siswa beranggapan bahwa menulis naskah drama merupakan kegiatan yang sulit, menjenuhkan, dan hanya orang-orang hebat yang dapat menulis naskah drama. Dilihat dari kesulitan yang dihadapi siswa kurang dalam paham dalam menentukan unsur intrinsik drama. Kesulitan tersebut tidak dijadikan tantangan bagi siswa untuk memahami dan menguasai pembelajaran menulis naskah drama, tetapi menjadikan mereka malas, tidak tertarik, dan bahkan tidak termotivasi mengikuti pembelajaran menulis naskah drama. Hal ini tentu berpengaruh pada tidak tercapainya tujuan pembelajaran yaitu siswa mampu menulis naskah drama dengan baik.

Hal ini disebabkan oleh beberapa faktor. Faktor-faktor tertentu antara lain siswa kurang mampu dalam memahami unsurunsur intrinsik teks drama. Kedua, kurangnya buku-buku sastra sebagai penunjang pembelajaran sastra. Ketiga, kurangnya minat siswa dalam pembelajaran sastra. Keempat, pengajaran sastra yang disajikan kurang bervariasi sehingga siswa tidak termotivasi dalam pembelajaran sastra khususnya dalam memahami unsur intrinsik dan esktrinsik drama.

Salah satu upaya perbaikan pembelajaran bahasa Indonesia di SMA Negeri 1 bagan Sinembah, Kab. Rokan Hilir, Provinsi Riau, dengan materi memahami unsurunsur intrinsik dan ekstrinsik teks drama dengan menerapkan metode diskusi dan presentasi. Penerapan metode diskusi dan presentasi merupakan salah satu sarana untuk mempermudah penyampaian materi dari guru kepada siswa. Dengan penerapan metode metode diskusi dan presentasi akan memberikan paradigma bahwa guru atau instruktur bukanlah satu-satunya sumber belajar. Guru hanya sebatas memfasilitasi pembelajaran di dalam kelasnya (Sanjaya, Wina. 2008). 
Selain itu penerapan metode presentasi dan diskusi diharapkan dapat meningkatkan kualitas proses pembelajaran. metode diskusi dan presentasi memberikan ruang bagi siswa untuk meningkatkan aktivitas dan kreativitas untuk mencari informasi terkait dengan materi yang disampaikan. Disamping itu dengan metode presentasi siswa dapat memanfaatkan media power point sebagai media pembelajaran. Dengan media yang digunakan dapat membantu siswa cepat memahami materi yang disampaikan.

Metode diskusi dan

presentasi merupakan penyajian langsung dengan cara bertukar pikiran, pendapat tentang suatu masalah (Santoso, 1995). metode diskusi dan presentasi digunakan untuk mentransfer ilmu secara efektif dan efisien, memotivasi, menumbuhkan kerja sama, belajar bertanggung jawab dalam penemuaan data serta dapat menciptakan proses belajar yang lebih menyenangkan (Joyfull learning). Selain itu pembelajaran dengan metode diskusi dan presentasi dapat menumbuhkan rasa percaya diri karena di dalam proses pembelajaran tersebut memungkinkan kemunculan berbagai kemampuan seperti kemampuan menganalisis masalah, kemampuan berpendapat serta kemampuan untuk mempertahankan pendapatnya/ pendapat kelompok.

Berdasarkan latar belakang masalah diatas guru akan melakukan perbaikan pembelajaran dengan
Penelitian Tindakan Kelas (PTK) pada mata pelajaran bahasa Indonesia yang berjudul "Penerapan Metode Diskusi dan Presentasi Untuk Meningkatkan Minat dan Hasil Belajar Siswa di Kelas XI IPS1 SMA Negeri 1 Bagan Sinembah"

Berdasarkan

Rumusan masalah di atas, adapun tujuan dari penelitian tindakan kelas ini adalah:

a. Untuk meningkatkan minat belajar siswa dengan penerapan metode diskusi dan presentasi di kelas XI IPS-1 SMA Negeri 1 Bagan Sinembah.

b. Untuk mengetahui ketuntasan hasil belajar bahasa Indonesia siswa di kelas XI IPS-1 SMA Negeri 1 Bagan Sinembah.

\section{MODEL PENELITIAN}

Desain Penelitian Kemmis merupakan pengembangan dari konsep dasar yang diperkenalkan Kurt Lewin. Desain penelitian Kemmis dikenal dengan model spiral. Hal ini karena dalam perencanaan, Kemmis menggunakan sistem spiral refleksi diri, yang dimulai dari rencana, tindakan, pengamatan, refleksi, dan perencanaan kembali merupakan dasar untuk suatu ancang-ancang pemecahan masalah. Perbedaan antara desain penelitian Kemmis dan Kurt Lewin adalah Kemmis menyatukan komponen tindakan (acting) dan pengamatan (observing). Disatukannya kedua komponen tersebut disebabkan oleh adanya kenyataan bahwa antara implementasi acting dan observing 
merupakan dua kegiatan yang tidak terpisahkan. Menurut Kemmis, dalam penelitian tindakan kelas dua kegiatan tersebut haruslah dilakukan dalam satu kesatuan waktu, begitu berlangsungnya satu tindakan begitu pula observasi juga dilakukan. Di dalam desain penelitian Kemmis dikenal sistem siklus. Artinya dalam satu siklus terdapat suatu putaran kegiatan yang terdiri dari perencanaan, tindakan, pengamatan, dan refleksi. Ketika siklus satu hampir berakhir, namun peneliti masih menemukan kekurangan ketika dilakukan refleksi peneliti bisa melanjutkan pada siklus kedua. Siklus kedua dengan masalah yang sama, namun teknik yang berbeda.

\section{HASIL PENELITIAN DAN PEMBAHASAN}

Berdasarkan kegiatan yang telah dilaksanakan pada setiap siklus, sebanyak dua siklus dalam penelitian tindakan kelas ini sebagai upaya meningkatkan minat dan hasil belajar siswa pada pembelajaran bahasa Indonesia di kelas XI IPS-1 SMA Negeri 1 Bagan Sinembah, dengan menggunakan metode pembelajaran diskusi dan presentasi pada laporan hasil pembahasan yang diuraikan sebagai berikut:

\section{Siklus I}

Hasil penerapan metode pembelajaran diskusi dan presentasi, untuk meningkatkan minat dan hasil belajar siswa, diperoleh hasil belajar siswa tertera pada gambar. 1 dibawah ini.

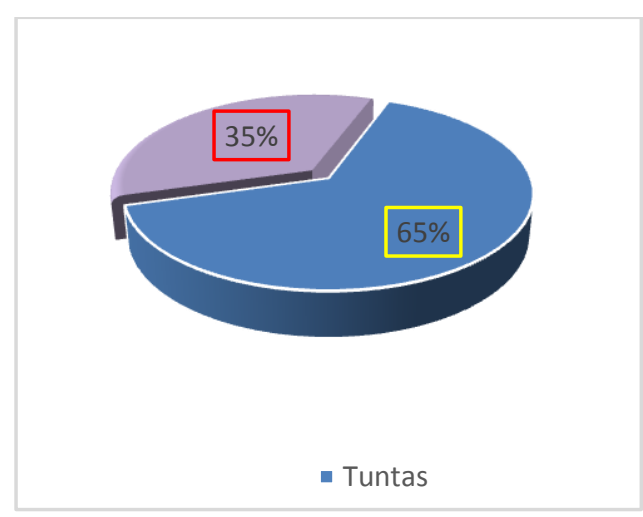

\section{Gambar 1. Hasil Siklus I}

Pada dan gambar 1 diperoleh hasil belajar siswa dalam pembelajaran bahasa Indonesia di kelas XI IPS-1 SMA Negeri 1 Bagan Sinembah Tahun Pelajaran 2015/2016, pada siklus I dari 40 orang siswa terdapat 26 siswa yang tuntas atau sekitar (65\%) dan 14 orang siswa yang tidak tuntas atau sekitar (35\%), dengan rerata 73,8. Perolehan hasil belajar ini sudah sangat baik, namun belum bisa ditakatan berhasil karena belum memperoleh ketuntasan klasikal dalam kelas yaitu sekitar $85 \%$ yang tuntas belajar, temuan hasil observasi diantaranya: 1) minat siswa sudah mulai menitkat walaupun perlu penambahan motivasi lagi agar siswa lebih semangat; 2) dari segi hasil belajar ditemuan kelemahan yaitu: a) ketajaman analisis masih kurang; b) pengungkapan argument analisis perrsamaan; c) kesimpulan hasil pembandingan unsur intrinsik dan intrinsik. Temuan ini menjadi perbaikan pada siklus II

\section{Siklus II}

Perencanaan siklus II disusun berdasarkan hasil refleksi dari 
kendala dan kelemahan yang ditemukan pada siklus I dari observasi penerapan metode pembelajaran diskusi dan presentasi, agar kendala dan kelemahan pada siklus I tidak terjadi lagi maka guru berupaya semaksimal mungkin untuk memberi motivasi dalam pembelajaran. Hasil belajar siswa dalam hal ini dapat dilihat pada gambar 2 dibawah ini.

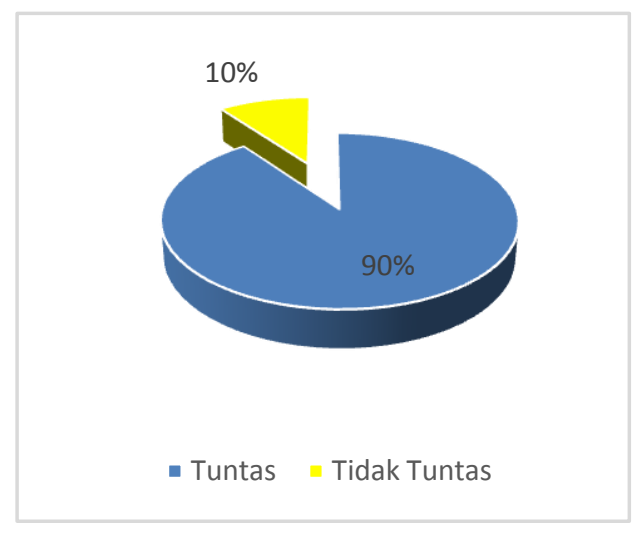

\section{Gambar 2. Siklus II}

\section{Pembahasan}

Hasil temuan penelitian tindakan kelas yang dilakukan di Kelas XI IPS-1 SMA Negeri 1 Bagan Sinembah Kab. Rokan Hilir pada mata pelajaran bahasa Indonesia ditinjau dari hasil belajar siswa dengan menerapkan metode pembelajaran diskusi dan presentasi dapat dilihat pada perbandingan siklus I dan Siklus II pada gambar 3 dibawah ini:

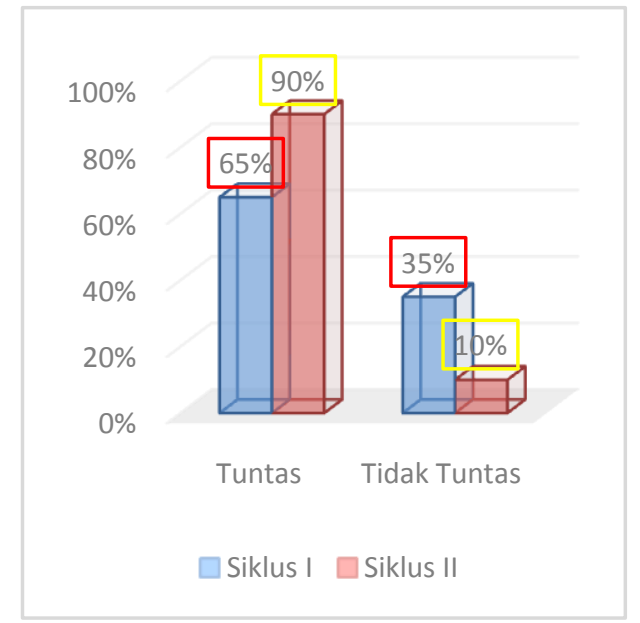

\section{Gambar 3. Perbandingan Siklus I dan Siklus II}

Gambar 3 tentang perbandingan hasil siswa dapat dilihat pada siklus I jumlah siswa yang tuntas 26 orang atau sekitar 65\% meningkat secara signifikan menjadi 36 orang atau sekitar $90 \%$ pada siklus II, untuk siswa yang tidak tuntas pada siklus I 14 orang atau sekitar 35\% menurut menjadi 4 orang atau sektiar $10 \%$ pada siklus II. Analisis pelaksanaan pembelajaran yang dilaksanakan oleh guru meliputi beberapa aspek, aspekaspek yang dinilai dari pelaksanaan pembelajaran memahami unsur intrinsik novel adalah keterampilanketerampilan dasar mengajar yang dikuasai oleh guru. Keterampilanketerampilan itu adalah (a) keterampilan membuka pelajaran, (b) keterampilan bertanya, (c) keterampilan menjelaskan, (d) keterampilan mengadakan variasi, (e) keterampilan memberi penguatan, (f) keterampilan mengelola kelas, (g) keterampilan membimbing diskusi kelompok kecil, (h) keterampilan mengajar kelompok kecil dan 
perorangan, serta (i) keterampilan menutup pelajaran. Sesuai dengan lembar observasi, hal-hal yang diamati dari pelaksanaan pembelajaran memahami unsur intrinsik dam ekstrinsik novel.

Dari pembahasa diatas dapat ditarik kesimpulan bahwa penerapan metode pembelajaran diskusi dan presentasi dapat meningkatkan minat dan hasil belajar siswa di Kelas XI IPS-1 SMA Negeri 1 Bagan Sinembah Kab. Rokan Hilir, temuan ini juga sejalan dengan temuan Erik Sutantik (2014) hasil dari penelitian yaitu metode presentasi dan diskusi dapat meningkatkan pemahaman unsur intrinsik dan ekstrinsik sastra.

\section{SIMPULAN}

Berdasarkan temuan hasil penelitian dengan judul "Penerapan Metode Diskusi dan Presentasi Untuk Meningkatkan Minat dan Hasil Belajar Siswa di Kelas XI IPS1 SMA Negeri 1 Bagan Sinembah", dapat ditarik kesimpulan sebagai berikut :

a. Hasil belajar siswa pada siklus I dari 40 orang siswa terdapat 26 siswa yang tuntas atau sekitar (65\%) dan 14 orang siswa yang tidak tuntas atau sekitar (35\%), dengan rerata 73,8 .

b. Hasil belajar siswa pada siklus II dari 40 orang siswa terdapat 36 siswa yang tuntas atau sekitar $(90 \%)$ dan 4 orang siswa yang tidak tuntas atau sekitar (10\%), dengan rerata 79,87 .

\section{DAFTAR RUJUKAN}

Abu, Ahmadi. 2009. Psikologi Umum. Jakarta: Rieka Cipta.

Djaali. 2008. Psikologi Pendidikan. Jakarta: Bumi Aksara.

Djamarah. Syaifu, Bahri. 2011. Psikologi Belajar. Jakarta: Rineka Cipta

Depdiknas. 2002. Keputusan Menteri Pendidikan Nasional RI tentang Pedoman Penyusunan Standar Pendidikan Dasar dan Menengah. Jakarta : CV.Mini Jaya Abadi

Erik Sutantik. 2014. Peningaktan Pemahaman Unsur Intrinsik dan Ekstrinsik Sastra Melalui Metode Presentasi dan diskusi.

Dinamika Jurnal Praktik Penelitian tindakan kelas Pendidikan Dasar dan Menegah Vol 6 no. 2

Mursini. 2012. Pengembangan Bahan Ajar Bahasa dan Sastra Indonesia. Medan: Unimed Press.

Rahmanto, B. 1993. Metode Pengajaran Sastra: Pegangan Guru Pengajar Sastra. Yogyakarta: Kanisius.

Sanjaya, Wina. 2008. Strategi Pembelajaran. Jakarta:

Kencana.

Slameto. 2010. Belajar dan faktorfaktor yang mempengaruhinya. Jakarta: PT Rineka Cipta.

Sudjana. 2004. Dasar-dasar proses belajar mengajar. Bandung: Baru.

Suprijono. 2013. Cooperative Leraning Teori dan 
Dortiana Marpaung : Penerapan Metode Diskusi dan ...

\author{
Aplikasinya Paikem.
}

Yogyakarta: Kanisius. 